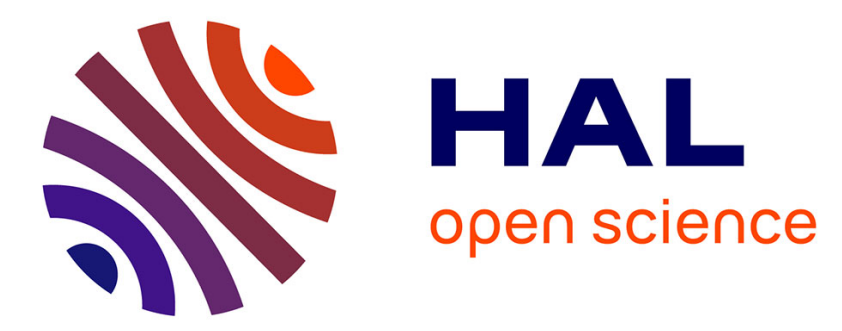

\title{
A re-description of Typhlodromus (Anthoseius) tamaricis (Kolodochka) (Mesostigmata: Phytoseiidae), a first record for Iran
}

\author{
B. Asali Fayaz, M. Khanjani, J. Hajizadeh, E.A. Ueckermann
}

\section{- To cite this version:}

B. Asali Fayaz, M. Khanjani, J. Hajizadeh, E.A. Ueckermann. A re-description of Typhlodromus (Anthoseius) tamaricis (Kolodochka) (Mesostigmata: Phytoseiidae), a first record for Iran. Acarologia, 2012, 52 (4), pp.425-431. 10.1051/acarologia/20122071 . hal-01567120

\author{
HAL Id: hal-01567120 \\ https://hal.science/hal-01567120
}

Submitted on 21 Jul 2017

HAL is a multi-disciplinary open access archive for the deposit and dissemination of scientific research documents, whether they are published or not. The documents may come from teaching and research institutions in France or abroad, or from public or private research centers.
L'archive ouverte pluridisciplinaire HAL, est destinée au dépôt et à la diffusion de documents scientifiques de niveau recherche, publiés ou non, émanant des établissements d'enseignement et de recherche français ou étrangers, des laboratoires publics ou privés.

\section{(1) (1) $\$$}

Distributed under a Creative Commons Attribution - NonCommercial - NoDerivatives| 4.0 


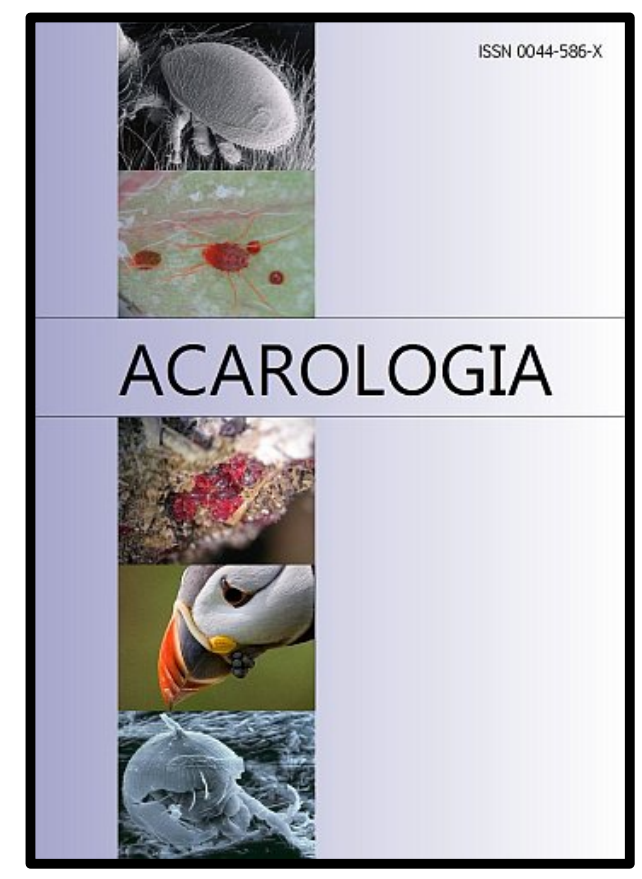

\section{ACAROLOGIA}

A quarterly journal of acarology, since 1959

Publishing on all aspects of the Acari

All information:

http://www1.montpellier.inra.fr/CBGP/acarologia/ acarologia@supagro.inra.fr

\section{OPEN ACCESS}

\section{Acarologia is proudly non-profit, with no page charges and free open access}

Please help us maintain this system by encouraging your institutes to subscribe to the print version of the journal and by sending us your high quality research on the Acari.

Subscriptions: Year 2017 (Volume 57): $380 €$ http://www1.montpellier.inra.fr/CBGP/acarologia/subscribe.php

Previous volumes (2010-2015): $250 € /$ year (4 issues)

Acarologia, CBGP, CS 30016, 34988 MONTFERRIER-sur-LEZ Cedex, France

The digitalization of Acarologia papers prior to 2000 was supported by Agropolis Fondation under the reference ID 1500-024 through the « Investissements d'avenir » programme

(Labex Agro: ANR-10-LABX-0001-01)
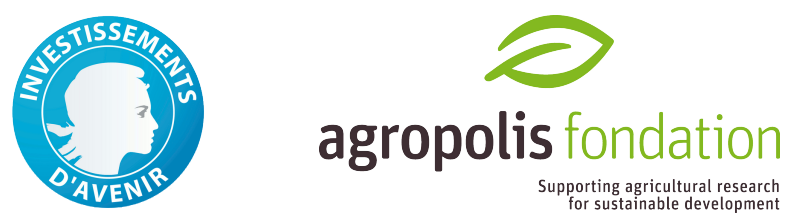

Acarologia is under free license and distributed under the terms of the

Creative Commons-BY-NC-ND which permits unrestricted non-commercial use, distribution, and reproduction in any medium, provided the original author and source are credited. 


\title{
A RE-DESCRIPTION OF TYPHLODROMUS (ANTHOSEIUS) TAMARICIS (KOLODOCHKA) (MESOSTIGMATA: PHYTOSEIIDAE), A FIRST RECORD FOR IRAN
}

\author{
Bahman AsAli FAYAZ ${ }^{1}$, Mohammad KHANJANi ${ }^{1 *}$, Jalil HAJIZADEH ${ }^{2}$ and \\ Edward A. UECKERMANN ${ }^{3,4}$
}

(Received 03 June 2012; accepted 19 July 2012; published online 21 December 2012)

\author{
${ }^{1}$ Department of Plant Protection, College of Agriculture, Bu Ali-Sina University, Hamedan, I.R. Iran. basalifayaz@gmail.com; \\ mkhanjani@gmail.com ( ${ }^{*}$ Corresponding author) \\ ${ }^{2}$ Department of Plant Protection, Faculty of Agricultural Sciences, Guilan University, Rasht, I.R. Iran. hajizadeh@guilan.ac.ir \\ 3 ARC-Plant Protection Research Institute, Private Bag X134, Queenswood, Pretoria, 0121 South Africa. UeckermannE@arc.agric.za \\ ${ }^{4}$ School of Environmental Sciences and Development, North-West University, Potchefstroom Campus 2520, South Africa
}

\begin{abstract}
This paper reports the re-description of a species belonging to the family Phytoseiidae. Typhlodromus (Anthoseius) tamaricis is the first record of the Iranian phytoseiid fauna which was collected on Tamarix gallica in the Heiran region, Ardabil province, Iran.
\end{abstract}

KEYWORDS - predatory mite; Phytoseiidae; Typhlodromus; Anthoseius; Iran

\section{INTRODUCTION}

Predatory mites belong to several families, but among them the family Phytoseiidae is the most important, as it contains effective bio-control agents which are currently used to control mite pests, thrips, and other small soft body insects in various crops all around the world (Chant 1985; Sabelis 1985; Chant and McMurttry 1994; McMutrty and Croft 1997; Walter and Beard 1997). They generally are the only members of the Mesostigmata that have extensively exploited the foliage of higher plants (Chant and McMurtry 2007). They are mostly reported from aerial parts of plants but can also be found soil litter. Although they mostly feed on spider mites and small insects, some of them can also survive on honeydew and pollen (McMurtry and Croft 1997; Van Rijn et al. 2002; Nomikou et al. 2003). Many phytoseiid mite species are actually generalist predators with only a few being prey specialists, though several have been shown to be host plant specific (Beard and Walter 2001). Currently, there are approximately 340 nominal species in the subgenus Typhlodromus (Anthoseius) De Leon, 1959 (Denmark and Evans 2011; Hernandes et al. 2011), but only 16 species were recorded from Iran (Daneshvar and Denmark 1982; Faraji et al. 2007; Ueckermann et al. 2009; Jafari et al. 2011; Moraes et al. 2004).

This sub-genus differs from the subgenus Typhlodromus (Typhlodromus) by the presence of the dorsal setae S5 and most species of them have the dorsal setal pattern 12A:8B. Anthoseius (Amblydromellus) tamaricis Kolodochka, 1982 was collected and described at first on Tamarix plants from Turk- 
Asali Fayaz B. et al.
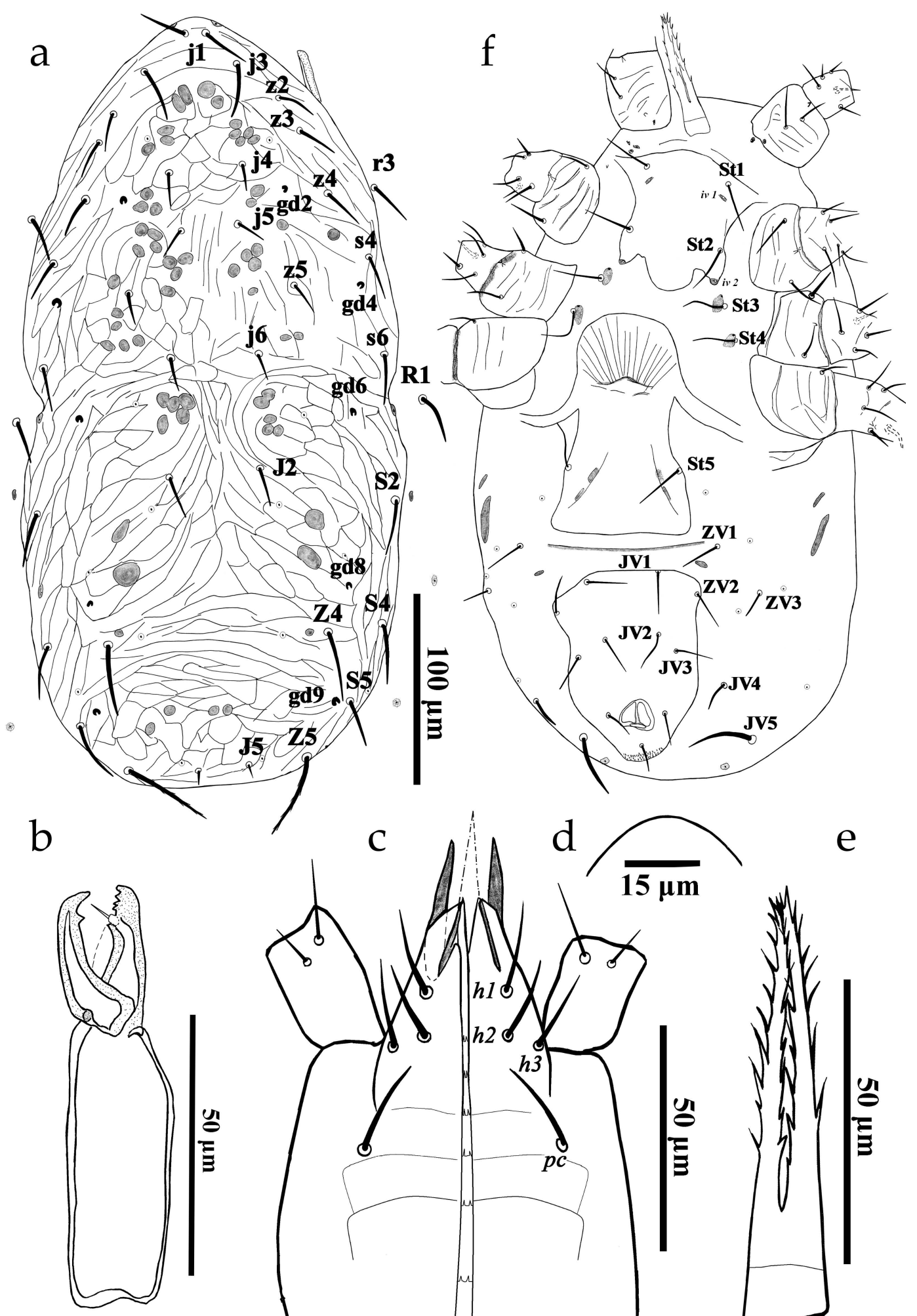

c $d /$

$\mathrm{e}$
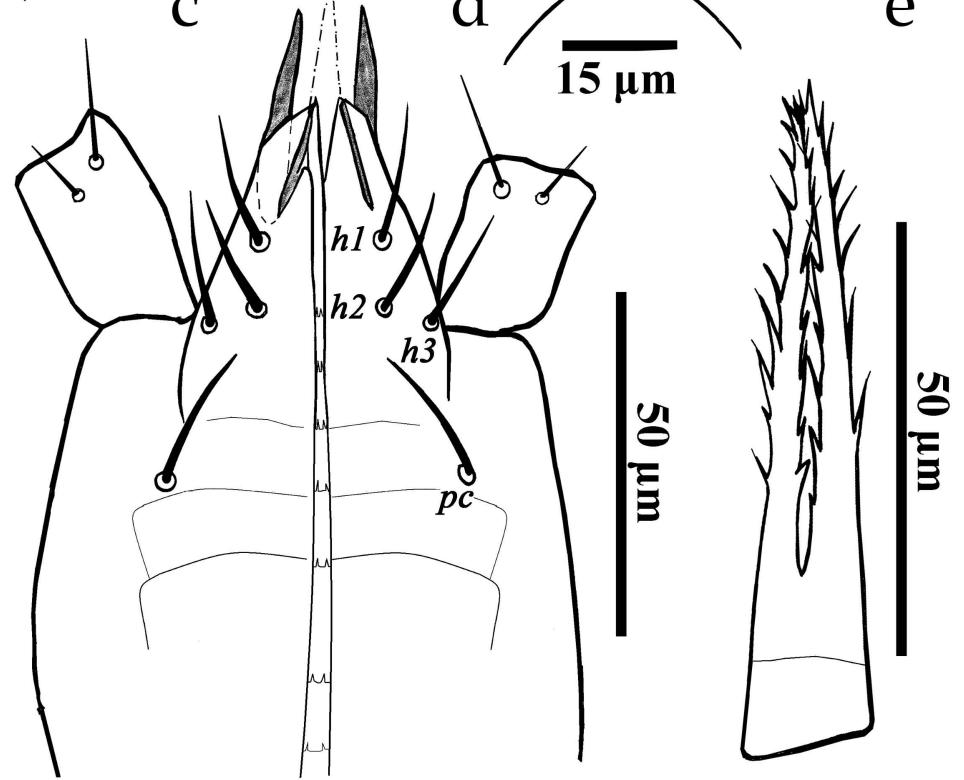

Figure 1: Typhlodromus (Anthoseius) tamaricis (female): a - Dorsal shield; b - Chelicerae; c - Hypostome; $\mathrm{d}$ - Tectum; $\mathrm{e}$ - Tritosternum; $\mathrm{f}$ - Ventral view of idiosoma. 
menistan. Later, it has been re-described as Typhlodromus (Anthoseius) tamaricis (Kolodochka) by Kasap and Çobanoğlu (2009) on the same plant host from Turkey. This paper provides more information on intraspecific variations and comparative characters among the original and Turkish species and constitutes the 17th species of this subgenus recorded from the Iranian phytoseiid fauna and also an identification key to the species of Typhlodromus (Anthoseius) known from Iran.

\section{MATERIALS AND METHODS}

Mites were collected from leaves of Salt cedar tree, Tamarix gallica L. (Tamaricaceae), using a stereomicroscope. The mites were then directly mounted on slides microscope in Hoyer's medium (Walter and Krantz 2009). The slides were dried in an oven at about $50^{\circ} \mathrm{C}$ and examined under an Olympus BX51 microscope (Differential Interference Contrast). A camera Lucida apparatus was used for the drawings. The classification system used follows that of Chant and McMurtry (2007). The setal notations follow the nomenclature proposed by Rowell et al. (1978) and dorsal setal pattern according to Chant and Yoshida-Shaul (1989); Organotaxy follow the nomenclature proposed by Athias-Henriot (1975). At last, terminology for spermatheca shape and morphology follows that of Wainstein (1973). All measurements are presented in micrometers $(\mu \mathrm{m})$. Also a key to Iranian Anthoseius species mites are presented.

\section{RESULTS \\ Re-description of \\ Typhlodromus (Anthoseius) tamaricis (Kolodochka)}

Family Phytoseiidae Berlese, 1916: 33. Typhlodromus Scheuten, 1857: 111. Sub-genus Anthoseius De Leon 1959: 258. Type species - Anthoseius hebetis De Leon 1959: 258. Typhlodromus (A.) tamaricis (Kolodochka, 1982).

Female (Figs. 1, 2) $(\mathrm{n}=2)$ - Idiosoma oval. Length of body (excluding palp) 391 (388 - 394); (including palp) $559(550-568)$. Idiosomal setal pattern: 12A:8A/JV:ZV. All idiosomal and leg setae smooth excluding Z5.

Dorsum (Fig. 1a) - Dorsal shield reticulated, 347 (335 - 358) long, $169(168$ - 170) wide at level of setae R1, with 17 pairs of smooth setae and 12 pairs of lyrifissures and five pairs of gland pores [solenostomes $(g d 2, g d 4, g d 6, g d 8, g d 9)$ ]. Length of setae: Lengths of setae: $j 121(20-22), j 324(23-$ 25), j4 14 (12 - 16), j5 15 (14 - 15), j6 17 (16 - 17), J2 19 (18 - 20), J5 7 (5 - 8), z2 17 (16 - 17), z3 18 (17 19), z4 21 (19-22), z5 $14(13-15), Z 433$ (30 - 35), Z5 46 (42 - 49), s4 19 (18 - 19), s6 24 (22 - 25), S2 27 (25 - 29), S4 29 (28 - 29), S5 24 (22 - 25), r3 21 (20 - 22), R1 22 (20 - 23). All setae smooth excluding Z5.

Gnathosoma (Figs. 1b-d) - Three pairs of smooth hypostomal setae, $h 1$ 21(20 - 21), h2 18 (16 - 20), h3 $19(18-20)$ long and palp coxa with a pair of smooth setae, $p c 23(21-25)$. Hypostomal groove with seven rows of denticles, each with two denticles, corniculi distally pointed (Fig. 1c); fixed digit of chelicera 28 long, with four teeth plus a pilus dentilis 4 long, movable digit $27(26-27)$ long and with a tooth (Fig. 1b); tectum convex $33(32-33)$ wide (Fig. 1d).

Venter (Figs. 1e-f) - Tritosternum 76 (74 - 77) long, with two barbed laciniae (Fig. 1e). Venter of idiosoma with 8 pairs of opisthogastric setae. Sternal shield smooth, posterior margin with a median lobe and with two pairs of setae of similar lengths [St1-2 24 (21-26)] and two pairs of lyrifissures (iv12); setae St3-4 set on small metasternal shields, each with one small lyrifissure. Genital shield 114 long, $75(72-78)$ wide at level of base and with a pair of setae, St5 $26(24-27)$ long. Two pairs of elongate metapodal shields, primary shield almost twice as long as secondary shield [27 (26-28), $14(13-14)]$. Ventrianal shield smooth, 108 (105 - 110) long and 87 (85 - 88) widest region, four pairs of pre-anal setae JV1 20, JV2 20, JV3 19, ZV2 20 long and without pre-anal pores; para-anal setae $P A 17$ and postanal seta PST $16(15-17)$ long. Opisthogastric cuticle bearing four pairs of setae on cuticle ZV1 21 (20 21), ZV3 13 (12 - 14), JV4 17 (16 - 17) and JV5 37 (33 - 40) long, all smooth; five pairs of lyrifissures and one pair of platelet and one elongate and slender transverse platelet between genital and ventrianal 


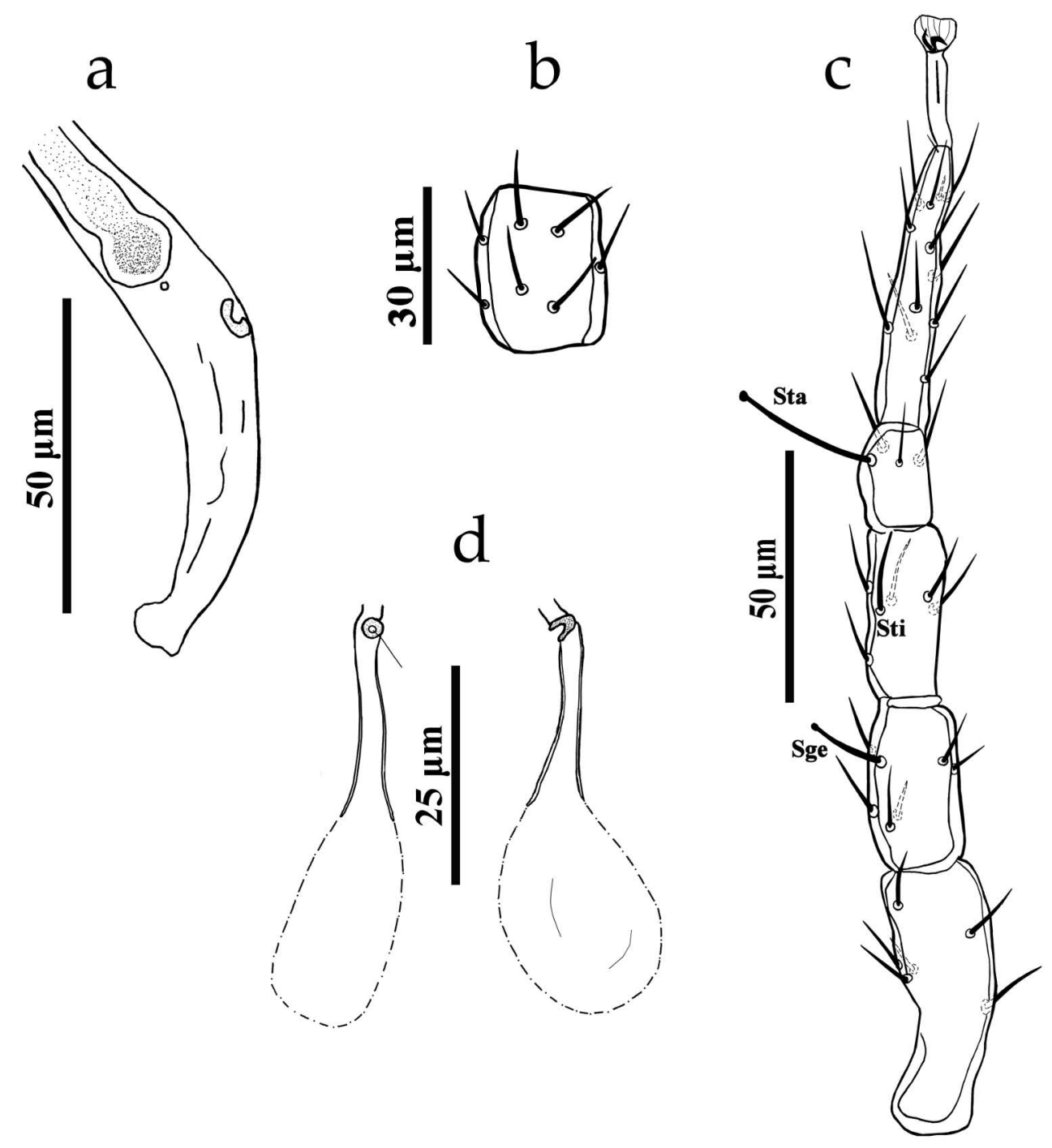

FIgURE 2: Typhlodromus (Anthoseius) tamaricis (female): a - Peritreme; b - Genu II; c - Leg IV; d - Spermatheca. 
shields (Fig. 1f).

Spermatheca (Fig. 2d) - Calyx tube-like 18 21 long and gradually flares towards vesicle; atrium completely occupied by lips, without neck between calyx and atrium, C shaped (Fig. 2d).

Peritreme (Figs. 1a, 2a) - Stippled; extending to level of setae j3, 208 (195 - 220) long.

Legs (Figs. 2b-c) - Length of legs (including pretarsus) as follows: Leg I 265, leg II 233 (230 235), leg III 238 (235 - 240) and leg IV 312 (307 317). Length of macrosetae as follows: Sge IV 18 (15 -21), knobbed; Sti IV 22 (21 - 22), pointed; Sta IV 39 (36 - 41), knobbed. Genua I-IV with 10-7-7-7 setae (Figs. 2b-c).

Material examined - The specimens were collected from the Salt cedar tree, Tamarix gallica L.: Tamaricaceae, in the Heiran region $\left(38^{\circ} 26^{\prime} \mathrm{N}, 48^{\circ}\right.$ $35^{\prime}$ E, $1474 \mathrm{~m}$ a. s. 1.), 28 ix 2008, Ardabil province, Iran, by B. Asali Fayaz. They have been deposited in the Collection of the Acarology Laboratory, University of Bu-Ali Sina, Hamedan, Iran.

Remarks - The Iranian specimens closely resemble the original description by Kolodochka (1982) from Turkmenistan and re-description of Kasap and Çobanoğlu (2009) from Turkey. However, we can note some morphological variation as follows: the posterior part of the sternal shield bears a median lobe in one out of the two Iranian specimens but is absent in Turkmen (personal communication) and Turkish specimens; sternal setae St3 is inserted on separate platelets in the former as on the soft cuticle of the body in the original description and Turkish re-description; a slender transversal linear plates between the genital and ventrianal shields in the Iranian specimen whereas four and five small linear plates are observed on the Turkmen and Turkish specimens, respectively; seta $Z 4$ and JV5 smooth in the present re-description whereas they are serrated in the Turkish specimens; primary metapodal shield more elongate in the Iranian and Turkmen specimens; measurement of dorsal setae: j3 $23-25$ and S5 $22-25$ Vs. 15 and 15 in the original description.

\section{Key to female Iranian Typhlodromus (Anthoseius) De Leon (Modified from Faraji et al. 2007).}

1. Ventrianal shield with three pairs of preanal setae................................... 2 - Ventrianal shield with four pairs of preanal setae................................... 4

2. Ventrianal shield with a pair of pores ......... 3

- Ventrianal shield without any pore............ .........T. (A.) rodriguezi (Denmark and Daneshvar)

3. Ventrianal shield with seta JV3, seta JV1 inserted out of Ventrianal shield, macroseta basitarsus IV 35 long ...... T. (A.) intercalaris Livshitz and Kuznetsov - Ventrianal shield without seta JV3, seta JV1 inserted on Ventrianal shield, macroseta basitarsus IV 52 long ............. T. (A.) haiastanius (Arutunjan)

4. Posterior opisthosomal seta Z5 knobbed apically.................................. 5 - Posterior opisthosomal seta Z5 pointed apically..................................6

5. Calyx of spermatheca tubular and narrow; movable digit of chelicera with one tooth; Z5 45 long; posterior margin of sternal shield concave.................. T. (A.) caudiglans Schuster - Calyx of spermatheca poculiform; movable digit of chelicera with two teeth; Z5 58 long; posterior margin of sternal shield with a median lobe.................. T. (A.) persianus McMurtry

6. Peritreme reaching seta $j 1$ or level between $j 1-j 3$

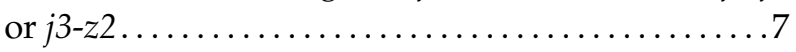

— Peritreme not reaching seta beyond $z 2 \ldots \ldots 13$

7. Dorsal shield heavily sclerotized; neck of spermatheca membranous ...... T. (A.) bakeri (Garman) - Dorsal shield not heavily sclerotized; spermatheca without membranous part............... 8

8. Movable digit of chelicerae with one tooth ....9 - Movable digit of chelicerae with more than one tooth...................................12 
9. Ventrianal shield without pore; two knobbed macrosetae on basitarsus and genu IV.

T. ( A.) tamaricis (Kolodochka)

- Ventrianal shield with a pair of pores, with one pointed macrosetae (setiform) on basitarsus IV, genu IV without macrosetae .............. 10

10. Calyx of spermatheca with a length: width ratio

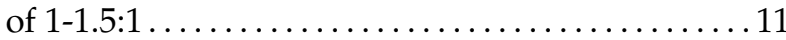
- Calyx of spermatheca with a length: width ratio of 2-2.5:1 .......... (A.) rhenanus (Oudemans)

11. Sternal shield with two pairs of setae. T. (A.) kerkirae Swirski and Ragusa - Sternal shield with three pairs of setae. T. (A.) georgicus Wainstein

12. Z5 66 long, movable digit of chelicerae with three teeth; $S 4$ shorter than $Z 4$ (about half) .. T. (A.) vulgaris Ehara

- Z5 55 long, movable digit of chelicerae with two teeth; $S 4$ subequal to Z4 ........ T. (A.) dalfardicus (Daneshvar)

13. Dorsal shield with 5 pairs of large pores $(g d 2$, $g d 4, g d 6, g d 8, g d 9)$; movable digit of chelicerae edentate........................ T. (A.) bagdasarjani Wainstein and Arutunjan [= T. (A.) kettanehi Dosse] - Dorsal shield with less than 5 pairs of large pores; movable digit of chelicerae with one tooth ..... 14

14. Dorsal shield with 4 pairs of large pores $(g d 2$, $g d 6, g d 8, g d 9) \ldots . \ldots . . T$. (A.) khosrovensis Arutunjan - Dorsal shield with 3 pairs of large pores $(g d 2$,

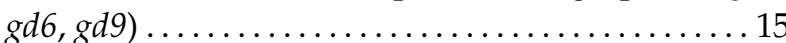

15. Ventrianal shield with a pair of pores........... ......T. (A.) neyshabouris (Denmark and Daneshvar) — Ventrianal shield without any pores ........ 16

16. Macroseta on basitarsus of leg IV with pointed tip (setiform) ...... T. (A.) torbatejamae (Denmark and Daneshvar) - Macroseta on basitarsus of leg IV with knobbed

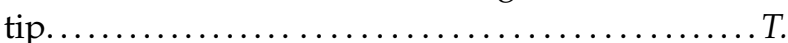

(A.) iranensis (Denmark and Daneshvar),suspected junior synonym of T. (A.) kazachstanicus Wainstein.

\section{ACKNOWLEDGEMENTS}

This paper is obtained from part of M. Sc. thesis of the senior author which was financially supported by vice research of Bu-Ali Sina University, Hamedan, Iran. The authors wish to thank Prof. G. J. De Moraes (Depto. Entomologia, Fitopatologia e Zoologia Agrícola, Universidade de São Paulo/ Escola Superior deAgricultura "Luiz de Queiroz", 13418-900 Piracicaba-SP, Brazil) for supplying some literatures.

\section{REFERENCES}

Athias-Henriot C. 1975 - Nouvelles notes sur les Amblyseiini. II. - Le relevé organotaxique de la face dorsale adulte (Gamasides, Protoadénique, Phytoseiidae) - Acarologia, 17(1): 20-29.

Beard J. J., Walter G. H. 2001 - Host plant specificity in several species of generalist mite predators - Ecol. Entomol., 26: 532-570. doi:10.1046/j.13652311.2001.00367.x

Berlese A. 1916 - Centuria prima di Acari nuovi. Redia., 12:19-66.

Chant D. A. 1985 - The Phytoseiidae. In: Helle, W. and Sabelis, M. W., Spider mites. Their biology, natural enemies and control - Elsevier Scince Publisher B. V., Vol. 1B, 4-33.

Chant D. A., McMurtry J. A. 1994 - A review of the subfamilies Phytoseiinae and Typhlodrominae (Acari: Phytoseiidae) - Internat. J. Acarol., 20(4): 223-310. doi:10.1080/01647959408684022

Chant D. A., McMurtry J. A. 2007 - Illustrated Keys and Diagnoses and Subgenera of the Phytoseiidae of the World (Acari: Mesostigmata) — Indira Publishing House, West Bloomfield, MI. 220 pp.

Chant D. A., Yoshida-Shaul E. 1989 - Adult dorsal setal patterns in the family Phytoseiidae (Acari: Gamasidae). Internat. J. Acarol., 15(4): 219-233. doi:10.1080/01647958908683852

Daneshvar H., Denmark H. A. 1982 - Phytoseiids of Iran (Acarina: Phytoseiidae) — Internat. J. Acarol., 8: 3-14. doi:10.1080/01647958208683272

De Leon D. 1959 - Two new genera of Phytoseiid mites with a note on Proprioseius meridionalis Chant (Acarina: Phytoseiide) — Entomol. News., 70(10): 257-262. 
Denmark H.A., Evans G.A. 2011 — Phytoseiidae of North America and Hawaii (Acari: Mesostigmata) - Indira Publishing House, West Bloomfield, MI. 451 pp.

Faraji F., Hajizadeh J., Ueckermann E. A., Kamali K., McMurtry J. A. 2007 - Two new records for Iranian Phytoseiid Mites with synonymy and keys to the species of Typhloseiulus Chant and McMurtry and Phytoseiidae in Iran (Acari: Mesostigmata) - Internat. J. Acarol., 33(3): 231-239. doi:10.1080/0647950708684527

Hernandes F. A., Kreiter S., Tixier M.-S. 2011 - Biogeographical analysis within the family Phytoseiidae Berlese (Acari: Mesostigmata): an example from the large sub-genus Typhlodromus (Anthoseius) De Leon Acarologia, 51(4): 431-448.

Jafari S., Fathipour Y., Faraji F. 2011 - Re-descriptions of Amblyseius meghriensis Arutunjan and Typhlodromus haiastanius (Arutunjan) with discussion on using preanal pores as a character in the subgenus Anthoseius (Mesostigmata: Phytoseiidae) — Internat. J. Acarol., 37 (3): 244-254.

Kasap I., Çobanolu S. 2009 - Phytoseiid mites of Hakkâri province, with Typhlodromus (Anthoseius) tamaricis Kolodochka, 1982 (Acari: Phytoseiidae), a new record for the predatory mite fauna of Turkey - Turkish J. Zool., 33(3): 301-308.

Kolodochka L. A. 1982 - New phytoseiid mites (Parasitiformes) Phytoseiidae from Turkmenia - Vestnik Zoologii, 6: 7-13.

McMurtry J. A., Croft B. A. 1997 - Life-styles of phytoseiid mites and their role in biological control - Annu. Rev. Entomol., 42: 291-321. doi:10.1146/anurev.ento.42.1.291

Moraes G. J. De., McMurtry J. A., Denmark H., Campos C. B. 2004 - A revised catalog of the mite family Phytoseiidae - Zootaxa, 434:1-494.

Nomikou M., Janssen A., Sabelis M. W. 2003 - Phytoseiid predators of whiteflies feed and reproduce on non-prey food sources - Exp. Appl. Acarol., 31: 1526. doi:10.1023/B:APPA.0000005142.31959.e8
Rowell H. J., Chant D. A., Hansell R. I. C. 1978 - The determination of setal homologies and setal patterns on the dorsal shield in the family Phytoseiidae (Acarina: Mesostigmata) - Can. Entomol., 110: 859-876. doi:10.4039/Ent110877-8

Sabelis M. W. 1985 - The Phytoseiidae. In: Helle, W. and Sabelis, M. W., Spider mites. Their biology, natural enemies and control - Elsevier Science Publisher B. V., Vol. 1B, 35-41.

Scheuten A. 1857 - Einiges uber Milben - Arch. Natur. Germany. 23: 104-112.

Ueckermann E. A., Jalaeian M., Saboori A., Seyedoleslami H. 2009 - Re-description of Typhlodromus (Anthoseius) khosrovensis, first record for Iran (Acari: Phytoseiidae) - Acarologia XLIX. (1-2): 23-27.

Van Rijn P. C. J., Van Houten Y.M., Sabelis M. W. $2002-$ How plants benefit from providing food to predators even when it is also edible to herbivores - Ecology. 88: 2664-2679.

Wainstein B. A. 1973 - On the structure of some organs of Phytoseiidae (Parasitiformes) important for taxonomy — Zool. Zh., 52: 1871-1872.

Walter D. E., Beard J. J. 1997 - A review of the Australian Phytoseiinae (Acari: Mesostigmata: Phytoseiidae) Invert. Taxon., 11: 823-860. doi:10.1071/IT97010

Walter D. E., Krantz G. W. 2009 - Collection, rearing and preparing specimens pp. 83-96. In: Krantz G. W., Walter D. (eds). A Manual of Acarology $3^{\text {rd }}$ ed. - Oregon State University Book Stores, Inc., Corvallis. 808 pp.

\section{COPYRIGHT}

(co) EY-No-ND Asali Fayaz B. et al. Acarologia is under free license. This open-access article is distributed under the terms of the Creative Commons-BY-NC-ND which permits unrestricted non-commercial use, distribution, and reproduction in any medium, provided the original author and source are credited. 